\title{
TOLFENPYRAD ANTIFEEDANT EFFECT ON SOME INSECTICIDES AGAINST COLORADO POTATO BEETLE Leptinotarsa decemlineata (SAY) (COLEOPTERA: CHRYSOMELIDAE)
}

\author{
Masood Hussein Mosa and Batool A. Karso \\ Dept. of Plant Protection, College of Agricultural Engineering Science, University of Duhok, \\ Kurdistan Region-Iraq
}

(Received: January 27, 2021; Accepted for Publication: March 30, 2021)

\begin{abstract}
The effect of the Antifeedant tolfenpyrad in the proportion of activation, synergy, and potentiation of pesticides oxaymatherin, acetamiprid, and lufenuron against Colorado beetle larvae and adults were studied. The results showed Exultance effect on Toxicity. The results also showed Exultance mixing Acetamiprid with antifeedant Tolfenopyrad pesticide toxicity to the activation of the pesticide in the larvae the third instar at a rate of 1.72, where was the rate of potentian reach 1.7. The antifeedant Tolfenopyrad mixture with insecticides Lufenuron and Oxymathrin each alone had antagonism effect where the activation rate reached 0.17 and 0.54 respectively. While the activation effect of mixing antifeedant Tolfenpyrad with the insecticides oxaymatherin, acetamiprid, and lufenuron against adult of Colorado beetle had antagonism effect reached $0.124,0.524$, and 0.614 , respectively.
\end{abstract}

KEYWORDS: Activation, Antifedants, Colorado beetle, Synergist

\section{INTRODUCTION}

$C^{\prime}$ olorado potato beetle Leptinotarsa decemlineata (Say) (Coleoptera: Chrysomelidae) is one of the most economically significant pests in world, launching year after year increasingly stronger attacks on potato fields (Ozturk \& Yildrim, 2012). The harmful stages consist of larvae and adults. Both are foliar pests and can eat more than $100 \mathrm{~cm}^{2}$ of leaf surface during their lifetime (Ozturk \& Yildrim, 2013). Colorado beetle was recorded in Iraq in 2003 (Al-Jorani, 2004).

Although, an effective and suitable control of this potato pests still lacking, mechanical control and chemical synthetic insecticides have been used widely to control this pest. But the extensive uses of chemical insecticides lead to several environmental and health problems such as pesticide poisoning, residual toxicity in water and soil and harmful effects to beneficial insects (Pavela, 2008). An intensive use of synthetic insecticides resulted in resistance of this pest in more than one case (Stanković et al., 2004; AlMallah, 2012), while the use of environmentally more acceptable substances show considerable efficacy in controlling this insect (Scott et al., 2003). These substances have not been generally applied until now. The reason for this situation can be attributed also to the slow mode of action of these substances, as many growers judge the efficacy of a pesticide according to its immediate effect. The adverse effects of continuous pesticides application encouraged the ecologists and others who care about the environment to look for stopping or reducing the pesticides applications. Much evidence that this invitation is unrealistic is the increase in pesticides' production and use because the pesticides are still the effective tool used for controlling pests (Meister, 2010).

Therefore, the aim of the present study is to evaluate the effectiveness of three insecticide mixtures (at different concentrations) with the antifeedant Tolfenpyrad, and then determine the effect of mixing on insecticides activity (inhibition or activation), and finally to find ecofriendly insecticides against Colorado beetle larvae and adults.

\section{MATERIAL AND METHODS}

\section{1- Colorado beetle culture :}

Adults of Colorado beetle (females and males) were collected from infested fields in Duhok province. Adults were placed in wooden cages $(75 \times 75 \times 75 \mathrm{~cm})$ which had one glass side, while the other sides were covered with 
sieves under growth chamber laboratory conditions $\left(26 \pm 28^{\circ} \mathrm{C}\right)$ in the Plant Protection Department, College of Agricultural Engineering Sciences, Duhok University. The cages were supplied daily with potato leaves, fixed inside a jar, and filled with water daily to keep the leaves fresh (Hassan 2019).

\section{2- Insecticides used:}

Four different groups of Insecticides were used:-

-Botanical pesticides (Oxymatrine, extract from Sophora plants).

- Growth regulators: Chitin synthesis inhibitors (Match) (active ingredients is Lufenuron $50 \mathrm{EC}$ ). -Neonicotinoids insecticide Mospilan AC. 20\% (active ingredient is Acetamprid) .

-Anti-feedant (Hachi hachi 15\%), active ingredient Tolfenpyrad $15 \%$. It considered as a new insecticides that recently introduced to Iraq in 2018, produced by Nihon Nohyaku Co. LTD, Tokyo, Japan.

\section{3- Insecticides preparation:}

To prepare the basic solution (one part volume of insecticide / million volume of water) water was used to make the required concentrations for dilution, and five concentrations $(0.5,1,3,5,10) \mathrm{ppm}$., were prepared from each pesticide (Oxymatrine, Acetamprid, Lufenuron and Tolfenpyrad).

\section{4- The effect of four different insecticides on Colorado beetle.}

The $3^{\text {rd }}$ instar larvae and adults were treated alone with the aforementioned concentrations by dipping the potato leaves in the insecticide's solution for two minutes and the leaves were left to dry (Tariq, 1997), after that 10 leaves placed in a plastic container of size $\left(25^{*} 15^{*} 10 \mathrm{~cm}\right)$ with a filter paper, and 10 adults and 10 larvae were added (each stage alone) by using a capillary brush. Three replicates/ concentration were determined; 10 adults/ replicate were used. For the control treatment, the leaves were treated with water only, then the packages were transferred to the incubator under the same rearing conditions, after 48 hour we record data to calculate Mortality $\%$ and corrected using Abbot Formula as

mortality $\%$ corrected (pesticide) $=(\%$ mortality of treatment (toxic substance) - \% mortality of control treatment) / (100 - \% mortality of control treatment) $* 100$.
5-The Effect of Antifeedant mixing with insecticides used against Colorado beetle Adults and $3^{\text {rd }}$ instar larvae.

The 3th instar larvae and adults of Colorado beetle were treated with different concentrations $(0.5,1,3,5,10) \%$ of mixing with ratio (1) Antifeedant :( 1) insecticide for each concentration with three replicates (ten individuals/replicate). For control treatment the larvae and adults were treated by water only, as we mentioned in paragraph (4). Then the larvae and adults stags were confined into Plastic package with diameter $25 * 15 * 10 \mathrm{~cm}$. and placed at room temperature $\left(27^{\circ} \mathrm{C}\right)$ for 48 hours to calculate the following:

A- Mortality \%

B- Activation ratio as well as the interactive between the activation, synergy, and potential of each mixing ratio was measured using the Metcalf (1972) equation.

Synergistic and relay ratios caused by stimulants were represented as \% mortality through the following steps:

-Correction of mortality rates of each mixture was made according to Al Mallah and Al-Jubury (2011). They represented the proportion of relay and humble to keep the synergistic impact only, as in the equation:

$\%$ mortality corrected $($ pesticide $)=(\%$ mortality of a mixture - \% mortality of anabolic substance) / (100 - \% mortality of anabolic substance) * 100.

-Lines of toxicity for the pesticide and its mixtures are separately used by the corrected $\%$ mortality calculated for each LC50 of the pesticide and its mixture.

-Calculate the proportion of synergistic effect using the Metcalf (1972) equation, which requires no toxic effect of the adjuvant.

-Ratio of synergistic effect $=$ LC50 value of the pesticide / LC50 value of the pesticide apron (mixture corrected).

-Total expense ratio of activation $=$ LC50 value of the pesticide / LC50 value of the mixture.

-Potential ratio $=$ ratio of activation - ratio of synergistic effect.

Data Analysis : the experiments will be designed as completely randomized design (CRD). The comparison between means will be carried out according to Duncan's multiple range test $(P<0.05)$ using a computerized program of SAS (SAS, 2001). 


\section{RESULTS}

1-The effects of different insecticides and their mixing on Colorado beetle adults

The data in table (1) showed significant differences among Colorado beetle adults treated with different concentrations of the insecticides (Tolfenopyrad, Acetampride, Lufenuron and Oxaymethrin). Where the best insecticide was oxaymethrin, gave the highest mortality rate reached $87 \%$ at concentration $10 \mathrm{ppm}$ and the general mortality caused by oxymatrine average was $58.8 \%$. Which confirms this result, its LC50 value, which reached $1.502 \mathrm{ppm}$, as well as the slope value of 1.3143, which indicates the homogeneity of the adult response to the pesticide.

May because there is no evidence to confirm the role of Oxaymethrin in controlling Colorado beetle, except Akdeniz and Ali (2014) mentioned that the extract's plants had been formulated as pesticides either alone or mixtures with conventional synthetic pesticides.This alkaloid has reduced the mitotic index in the Allium root meristem in higher concentrations but hasn't shown distinct genotoxic effects (Jermy, 1971) and (Duraipandiyan, et. al. 2011). The lowest mortality percentage was recorded when the Colorado adults treated with lufenuron as $7 \%$ at $0.5 \mathrm{ppm}$ with an average mortality rate of $18.8,22.6$ and $17.8 \%$ respectively. These result confirmed by their LC50 value, which reached 41,17 , and $45 \mathrm{ppm}$ which is the concentration that kills half the number of adults treated with the pesticide.

The data in table (2) showed that the average mortality \% recorded with adults treated with Antifeedant (tolfenopyrad) mixed with Oxymathrin varied significantly compared with Antifeedant (tolfenopyrad) and Lufenuron with highest mortality percent reaching $64 \%$ at 10 ppm.

The results also showed that the average \% mortality in the adults treated with a mixture Antifeedant (tolfenopyrad) and lufenuron recorded zero $\%$ at 0.5 and $1 \mathrm{ppm}$.

\section{2- Effect of insecticides mixing on Colorado beetle third instar larvae stags}

The data in table (3) showed significant differences among $3^{\text {rd }}$ instar larvae treated with different concentrations of Antifeedant (tolfenopyrad), Acetampride, Lufenuron, and Oxamethrin. The oxaymethrin had the best effect on the larvae, as it gave the highest mortality percent as $100 \%$ at both 5 and $10 \mathrm{ppm}$ concentration with the general mortality average was $90.45 \%$ and LC50 was 0.169 ppm, as well as the slope value was 1.348 .

Although there is no evidence to confirm the role of Oxamethrin in controlling the Colorado beetle because it is a modern pesticide, except (Akdeniz and Ali, 2014), confirmed plant extracts had been formulated as pesticides either alone or in mixtures with conventional synthetic pesticides.

The lowest mortality percentage was when the $3^{\text {rd }}$ instar larvae treated with Acetampride (Mospilan) pesticide as $7 \%$ at $0.5 \mathrm{ppm}$ and $40 \%$ average mortality this result confirmed by LC50 value, which reached $3.963 \mathrm{ppm}$, and the slope value of 1.458. (Table 3). Also, Bozov and Yoana (2017) when they test Fourteen neoclerodane diterpenoids isolated from Scutellaria altissimo (Lamiaceae) as insects antifeedant against Leptinotarsa decemlineata (Say) by treating the Potato leafs disks with small amounts of the compounds with (concentration $1000,100,10 \mathrm{ppm}$. They gave very good results as the antifeedant activity reached $50 \%$. While, Koul et.al. (2003) mentioned that the biological activity of the limonoids prieurianin and epoxyprieurianin were assessed using the gram pod borer, Helicoverpa armigera (Hubner) (Lepidoptera: Noctuidae). Found that the antifeedant activity alone non-toxicity, and un significant effect on nutritional indices following topical application, further suggesting that prieurianin-type limonoids act specifically as feeding deterrents.( Jermy,1971) and ( Duraipandiyan, et. al. 2011).

Generally, the results (Table 3) showed that the mean average of mortality in Colorado beetles $3^{\text {rd }}$ instar larvae treated with Oxymathrin gave the highest average mortality rate reached $90.45 \%$, while Match insecticide gave the lowest mean avarege reached $34.64 \%$.

From the data in Table 4, the results showed significant differences in mortality average of Colorado beetle's $3^{\text {rd }}$ instar larvae treated with tolfenopyrad mixed with Oxymathrin and has varied significantly depending on the concentration used in the mixture, The highest average mortality $\%$ reached $87 \%$ at $10 \mathrm{ppm}$, followed by the mixture of tolfenopyrad and acetamiprid as, $73.3 \%$ at the same concentration, while the lowest mortality was $6 \%$ at the concentration of $0.5 \mathrm{ppm}$ in the larvae 
treated with a mixture of Antifeedant (Tolfenopyrad) and match.

Generally, the results shown that the mixing Antifeedant (Tolfenopyrad) with oxymatrine gave the highest mean mortality percentage reached $51.2 \%$, and it gave the least value of LC50 (31.51) this indicated the toxicity of the Antifeedant (Tolfenopyrad) mixture (Table 4).

Finally, it is evident from a table (5), there are significant differences in the effect of the type of pesticides, and their mixtures on responding of the Colorado beetle ( adult, and the third instar larvae ) in the percentage, that the best mortality percentage found when the adults and larvae treated with oxymethrine as $58.8 \%$ and $90.45 \%$, respectively.

The lowest mortality recorded with a mixture of tolfenopyrad and Match insecticide as 3.8 and $13.6 \%$ for adults and larvae, respectively.

Table (1): The effect of insecticides type and concentrations on Colorado beetle adults.

\begin{tabular}{|c|c|c|c|c|c|c|}
\hline Insecticide's type & Con. \% & $\begin{array}{l}\text { Mortality } \\
\text { Percentage }\end{array}$ & Means & LC50 value & Slope & Conf. \\
\hline \multirow{5}{*}{$\begin{array}{l}\text { Antifeedant } \\
\text { (tolfenopyrad) }\end{array}$} & 0.5 & $7 \mathrm{f}$ & \multirow[t]{5}{*}{$18.8 \mathrm{~b}$} & \multirow[t]{5}{*}{41.82} & \multirow[t]{5}{*}{0.7285} & \multirow{5}{*}{$\begin{array}{l}19.541 \\
306.107\end{array}$} \\
\hline & 1 & 14 ef & & & & \\
\hline & 3 & 18 ef & & & & \\
\hline & 5 & 20 def & & & & \\
\hline & 10 & $35 \mathrm{~cd}$ & & & & \\
\hline \multirow{5}{*}{ (Acetampride) } & 0.5 & $7 \mathrm{f}$ & \multirow[t]{5}{*}{$22.6 \mathrm{~b}$} & \multirow[t]{5}{*}{17.554} & \multirow[t]{5}{*}{0.9520} & \multirow{5}{*}{$\begin{array}{l}10.807 \\
40.633\end{array}$} \\
\hline & 1 & 14 ef & & & & \\
\hline & 3 & 20 def & & & & \\
\hline & 5 & 28 cde & & & & \\
\hline & 10 & $44 \mathrm{c}$ & & & & \\
\hline \multirow{5}{*}{ (Lufenuron) } & 0.5 & $7 \mathrm{f}$ & \multirow[t]{5}{*}{$17.8 \mathrm{~b}$} & \multirow[t]{5}{*}{45.922} & \multirow[t]{5}{*}{0.79856} & \multirow{5}{*}{$\begin{array}{l}18.843- \\
209.586\end{array}$} \\
\hline & 1 & $9 \mathrm{f}$ & & & & \\
\hline & 3 & 20 def & & & & \\
\hline & 5 & 20 def & & & & \\
\hline & 10 & $33 \mathrm{~cd}$ & & & & \\
\hline \multirow[t]{5}{*}{ Oxymathrin } & 0.5 & 27 cde & \multirow[t]{5}{*}{$58.8 \mathrm{a}$} & \multirow[t]{5}{*}{1.502} & \multirow[t]{5}{*}{1.3143} & \multirow{5}{*}{$\begin{array}{l}1.182- \\
1.854\end{array}$} \\
\hline & 1 & $40 \mathrm{c}$ & & & & \\
\hline & 3 & $67 \mathrm{~b}$ & & & & \\
\hline & 5 & $73 \mathrm{ab}$ & & & & \\
\hline & 10 & $87 \mathrm{a}$ & & & & \\
\hline
\end{tabular}

Values sharing the same letter within the same columns are not differ according to the Duncan Multiple Range Test (0.05)

Table (2): The effect of insecticides mixture and their concentrations on Colorado beetle adults.

\begin{tabular}{|c|c|c|c|c|c|c|}
\hline $\begin{array}{l}\text { Insecticide's } \\
\text { mixing type }\end{array}$ & $\begin{array}{l}\text { Con. } \\
\text { Ppm. }\end{array}$ & $\begin{array}{l}\text { Mortality } \\
\text { Percentage }\end{array}$ & Means & LC50 value & Slope & Conf. \\
\hline \multirow{5}{*}{$\begin{array}{l}\text { Antifeedant } \\
\text { (tolfenopyrad)+ } \\
\text { Oxymatrine }\end{array}$} & 0.5 & 10 cdef & \multirow[t]{5}{*}{$27 \mathrm{a}$} & \multirow[t]{5}{*}{13.15} & \multirow[t]{5}{*}{1.128} & \multirow{5}{*}{$\begin{array}{l}0.292- \\
2.5476\end{array}$} \\
\hline & 1 & 13 cde & & & & \\
\hline & 3 & 17 cde & & & & \\
\hline & 5 & $21 \mathrm{bcd}$ & & & & \\
\hline & 10 & $64 \mathrm{a}$ & & & & \\
\hline \multirow{5}{*}{$\begin{array}{l}\text { Antifeedant } \\
\text { (tolfenopyrad)+ } \\
\text { Acetamprid }\end{array}$} & 0.5 & 10 cdef & \multirow[t]{5}{*}{$24.4 \mathrm{a}$} & \multirow{5}{*}{$\begin{array}{l}33.472 \\
124.6\end{array}$} & \multirow[t]{5}{*}{0.4348} & \multirow{5}{*}{$\begin{array}{l}0.31428- \\
1.1839\end{array}$} \\
\hline & 1 & 20 bcd & & & & \\
\hline & 3 & $26 \mathrm{bc}$ & & & & \\
\hline & 5 & $30 \mathrm{~b}$ & & & & \\
\hline & 10 & $36 \mathrm{~b}$ & & & & \\
\hline \multirow{5}{*}{$\begin{array}{l}\text { Antifeedant } \\
\text { (tolfenopyrad)+ } \\
\text { Lufenuron }\end{array}$} & 0.5 & $0 \mathrm{f}$ & \multirow[t]{5}{*}{$3.8 \mathrm{~b}$} & \multirow[t]{5}{*}{66.6} & \multirow[t]{5}{*}{1.47} & \\
\hline & 1 & $0 \mathrm{f}$ & & & & \\
\hline & 3 & 3.3 ef & & & & \\
\hline & 5 & 6 def & & & & \\
\hline & 10 & 10 cdef & & & & \\
\hline
\end{tabular}

Values sharing the same letter within the same columns are not differ according to the Duncan Multiple Range Test (0.05) 
Table (3): The effect of insecticides type and their concentrations on Colorado beetle $3^{\text {rd }}$ instar larvae.

\begin{tabular}{|c|c|c|c|c|c|c|}
\hline type Insecticide's & Con. Ppm & $\begin{array}{l}\text { Mortality } \\
\text { Percentage }\end{array}$ & Means & LC50 value & Slope & Conf. \\
\hline \multirow{5}{*}{$\begin{array}{l}\text { Antifeedant } \\
\text { (tolfenopyrad) }\end{array}$} & 0.5 & $24 \mathrm{fgh}$ & \multirow[t]{5}{*}{$43.2 \mathrm{c}$} & \multirow[t]{5}{*}{4.30} & \multirow[t]{5}{*}{0.768} & \multirow{5}{*}{$\begin{array}{l}3.053- \\
6.872\end{array}$} \\
\hline & 1 & 34 efg & & & & \\
\hline & 3 & 40 ef & & & & \\
\hline & 5 & $50 \mathrm{de}$ & & & & \\
\hline & 10 & $65 \mathrm{~cd}$ & & & & \\
\hline \multirow{5}{*}{ Acetampride } & 0.5 & $7 \mathrm{~h}$ & \multirow[t]{5}{*}{$40 \mathrm{~b}$} & \multirow[t]{5}{*}{3.963} & \multirow[t]{5}{*}{1.458} & \multirow{5}{*}{$\begin{array}{l}3.269- \\
4.924\end{array}$} \\
\hline & 1 & $22 \mathrm{gh}$ & & & & \\
\hline & 3 & 44 ef & & & & \\
\hline & 5 & $57 \mathrm{~cd}$ & & & & \\
\hline & 10 & $70 \mathrm{c}$ & & & & \\
\hline \multirow{5}{*}{ Lufenuron } & 0.5 & $20 \mathrm{gh}$ & \multirow[t]{5}{*}{$34.64 \mathrm{~d}$} & \multirow[t]{5}{*}{11.728} & \multirow[t]{5}{*}{0.589} & \multirow[t]{5}{*}{$6.286-47.2$} \\
\hline & 1 & $26.6 \mathrm{fgh}$ & & & & \\
\hline & 3 & 33.3 efg & & & & \\
\hline & 5 & 40 ef & & & & \\
\hline & 10 & $53.3 \mathrm{~d}$ & & & & \\
\hline \multirow[t]{5}{*}{ Oxymathrin } & 0.5 & $76.16 \mathrm{bc}$ & \multirow[t]{5}{*}{$90.45 a$} & \multirow[t]{5}{*}{0.169} & \multirow[t]{5}{*}{1.348} & \multirow{5}{*}{$\begin{array}{l}0.1098- \\
0.588\end{array}$} \\
\hline & 1 & $85.7 \mathrm{ab}$ & & & & \\
\hline & 3 & $90.4 \mathrm{ab}$ & & & & \\
\hline & 5 & $100 \mathrm{a}$ & & & & \\
\hline & 10 & $100 \mathrm{a}$ & & & & \\
\hline
\end{tabular}

Values sharing the same letter within the same columns are not differ according to the Duncan Multiple Range Test $(0.05)$

Table (4): The effect of insecticides mixture and their concentrations on Colorado beetle $3^{\text {rd }}$ instar

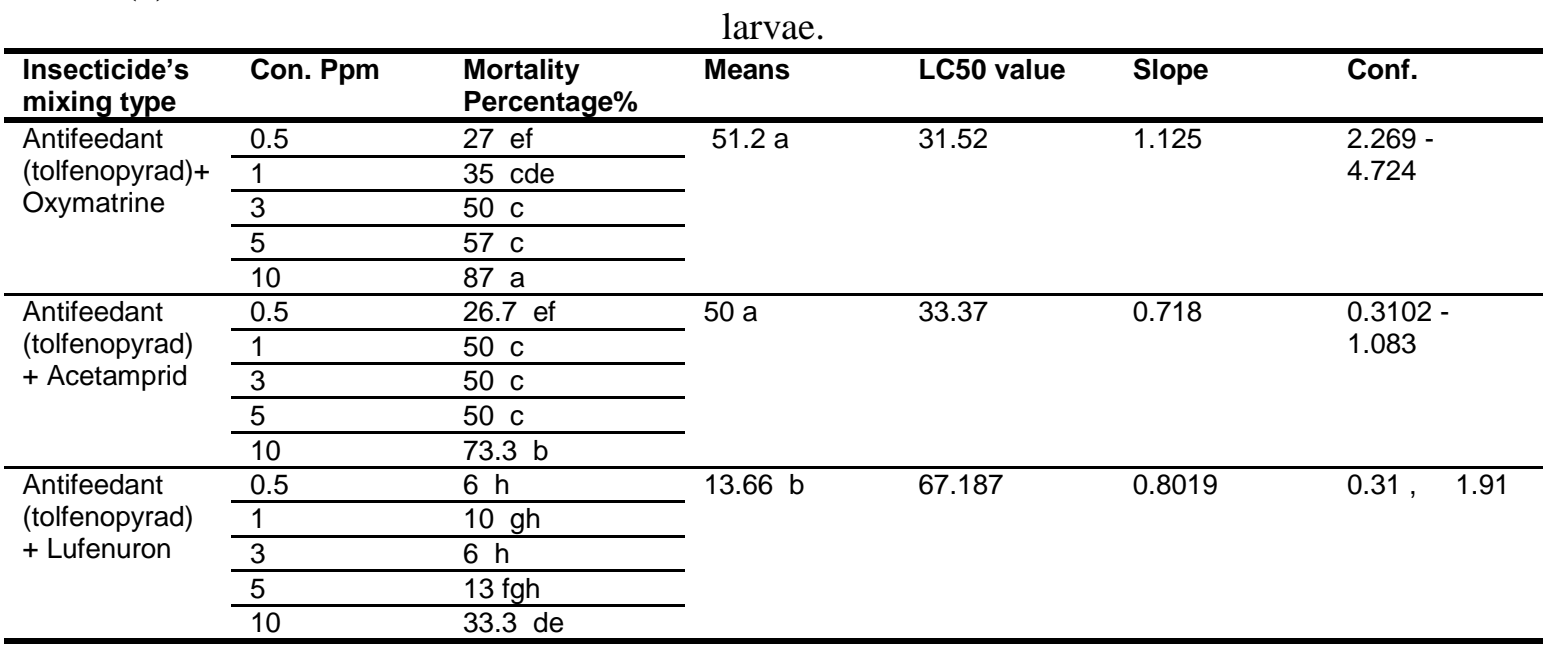

Values sharing the same letter within the same columns are not differ according to the Duncan Multiple Range Test (0.05)

Table (5) ; The mean Mortality percentage and LC50 value of insecticides type and their mixtures on Colorado beetle larvae and adults.

\begin{tabular}{lcccc}
\hline $\begin{array}{l}\text { Insecticides' type } \\
\text { and Mixture }\end{array}$ & Mortality \% & $\begin{array}{l}\text { Lc50 value of } \\
\text { insecticides }\end{array}$ & Mortality \% & $\begin{array}{l}\text { Lc50 value of } \\
\text { insecticides }\end{array}$ \\
\cline { 2 - 5 } & 18.8 ef & 45.82 & $43.2 \mathrm{~d}$ & 4.30 \\
\hline $\begin{array}{l}\text { Antifeedant } \\
\text { (Tolfenopyrad) }\end{array}$ & $58.8 \mathrm{c}$ & 1.502 & $90.45 \mathrm{a}$ & 0.169 \\
\hline Oxymatrine & & & & \\
\hline
\end{tabular}

masood.mosa@uod.ac 


\begin{tabular}{lcccc}
\hline Acetamprid & $22.6 \mathrm{e}$ & 17.554 & $76 \mathrm{~b}$ & 3.963 \\
\hline Lufenuron & $17.8 \mathrm{ef}$ & 40.922 & $34.64 \mathrm{de}$ & 11.728 \\
\hline Tolfen.+ Oxym. & $27 \mathrm{e}$ & 13.15 & $51.2 \mathrm{c}$ & 31.52 \\
\hline Tolfeno.+Acetamprid. & $24.4 \mathrm{e}$ & 33.47 & $50 \mathrm{c}$ & 33.37 \\
\hline Tolfeno.+Lufenuron & $3.8 \mathrm{~g}$ & 66.6 & $13.66 \mathrm{f}$ & 67.187 \\
\hline
\end{tabular}

Values sharing the same letter within the same columns are not differ according to the Duncan Multiple Range Test (0.05)

3- Effect of Antifeedant (tolfenopyrad) on activation, synergism, and potential ratio of Acetamprid, Match, and oxaymethrin against Colorado beetle larvae and Adults.

For adults; Synergism ratios of mixing antifeedants tolfenopyrad with insecticide varied according to the type of insecticide used. Statistical analysis showed significant differences in the rates of activation at the level of $0.5 \%$, depending on the factors that the highest synergy 0.524 was given by the mixture tolfenopyrad with Acetameprid, while the least synergy ratio 0.34 appeared at the mixture of Tolfenopyrad (Table 6).

The highest potentiation reached (0.58), found in the mixture of Tolfenopyrad and Lufenuron. The highest activation (0.614) was recorded for the mixture of Tolfenopyrad with lufenuron. In general, the effect of mixing of antifeedant with insecticides (Oxymethrine, Acetamiprid, and Lufenuron) on adults mortality was antagonism effect reached $(0.124,0.524$, and 0.614) respectively (Table 6).

For Larvae; Synergism ratios of mixing Tolfenopyrad with insecticide varied according to the type of insecticide used. The highest synergy 0.0403 was given by the mixture Antifeedant (Tolfenopyrad) with Oxymatrine, while the least synergy ratio 0.0154 appeared at the mixture of Lufenuron (Table7). The highest potentiation (1.7) found in the mixture of Antifeedant (tolfenopyrad) and acetamiprid. The highest activation (1.72) recorded for the mixing of Tolfenopyrad and acetamiprid.

Generally, the effectiveness of mixing of Tolfenopyrad with insecticides (Oxymatrine, and Lufenuron) on mortality against the third instar larvae was antagonism effect reached $0.54,0.17$ ) respectively. And the Antifeedant (tolfenopyrad) mixture with acetamiprid was the activation effect (Table7).

The results obtained showed that the Antifeedant tolfenopyrad used in this study had synergistic effects on the pesticide, and this is inconsistent with several studies. Sun and Johnson (1960) and Shaaban and Al Mallah (1993) reported that the synergies mainly depend on the materials that may be motivated or inhibit the enzymes on the chemical composition of pesticides. O'Brien (1967) mentioned that increasing the toxicity of pesticides by adding synergies materials depends on several factors, like the increased speed of entry into force of the pesticide through the body and arrival at the target sites. Wilkinson (1979) reported that the additives materials be inhibit the enzymes responsible for the removal of toxic pesticides within the body of the insect, thus leading to the accumulation of active ingredient of the pesticide and the speed of killings.

Although rates of activation and antagonism differences depend on the type of insecticides and an insect's stage. Results showed that the larvae were more sensitive than adults led to the activation. 
Table (6): Effect of Tolfenopyrad mixture with the insecticides on the activation, synergism, and potentiation percentage on the adults of Colorado beetle.

\begin{tabular}{cccc}
\hline $\begin{array}{l}\text { Insecticides' } \\
\text { type }\end{array}$ & Activation & Synergism & Potentiation \\
\hline Oxymathrin & 0.124 & 0.039 & 0.085 \\
\hline Acetameprid & 0.524 & 0.524 & 0 \\
\hline Lufenuron & 0.614 & 0.034 & 0.58 \\
\hline
\end{tabular}

Table (7): Effect of Tolfenopyrad mixture with the insecticides on the activation, synergism and potentiation percentage on the Larvae of Colorado beetle .

\begin{tabular}{cccc}
\hline Insecticides' type & Activation & Synergism & Potentiation \\
& & & \\
\hline Oxymathrin & 0.54 & 0.0403 & 0.539 \\
\hline Acetameprid & 1.72 & 0.02 & 1.7 \\
\hline Lufenuron & 0.17 & 0.0154 & 0.155 \\
\hline
\end{tabular}

\section{REFERENCES}

$$
\begin{aligned}
& \text { الملاح , نزار مصطفى و عبد الرزاق يونس الجبوري. ( } 2011 \text { ) . }
\end{aligned}
$$

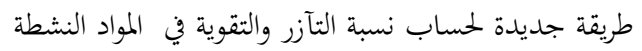

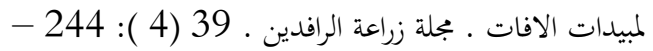

$$
\begin{aligned}
& 249 \\
& \text { الملاح , نزار مصطفى وعبد الرزاق يونس. ( } 2012 \text { ) ـ المبيدات } \\
& \text { الكيميائية , مجاميعها وطرائق تأثيرها وتأييضها } \\
& \text { في الكائنات والبيئة ـ دار العلا , موصل ـ العراق. ص213 } \\
& \text {. } 217 \text { - } \\
& \text { شعبان , عواد ونزار مصطفى الملاح. ( } 1993 \text { ) . المبيدات ـ وزارة }
\end{aligned}
$$

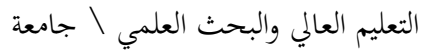

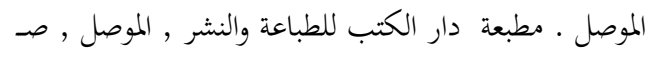

$$
\begin{aligned}
& .520
\end{aligned}
$$

Abbot W S 1 .(1925). A method for computing the effectiveness on insecticides. Journal of Economic Entomology. 18 : 265 - 267.

Bozov PI and Georgieva YP..(2017). Antifeedant Activity of Neo-clerodane Diterpenoids from Scutellaria altissima against Colorado Potato Beetle Larvae. Natural product communications. 12(3):327-328.

Duraipandiyan V, Ignacimuthu S and Paulraj M G .(2011). Antifeedant and larvicidal activities of Rhein isolated from the flowers of Cassia fistula L. Saudi J Biol Sci.; 18(2): 129-133.
Hassan F.R. 2019. Selective Isolation and Biomass Production of Beauveria bassiana and its Virulence to Squash Beetle Epilachna chrysomelina F. Ph.D dissertation,College of Agricultural Engineering Sciences / University of Duhok,Iraq. 165pp.

Jermy T. (1971). Biological background and outlook of the antifeedants approach to insect control. Acta Phytopathol. Acad. Sci. Hung. 6, $253-$ 260.

Koul, Opender , Wlodzimierz Daniewski M , Multani J S , Gumulka M and Singh G. (2003). Antifeedant Effects of the Limonoids from Entandrophragma candolei (Meliaceae) on the Gram Pod Borer, Helicoverpa armigera (Lepidoptera: Noctuidae). J. Agric. Food Chem. 51, 25, 7271-7275.

Laznik Ž, Tóth T, Lakatos, Vidrih T M, and Trdan S. (2010). Control of the Colorado potato beetle(Leptinotarsa decemlineata [Say]) on potato under field conditions: a comparison of the efficacy of foliar application of two strains ofSteinernema feltiae (Filipjev) and spraying with thiametoxam. Journal ofPlant Diseases and Protection,117, 129- 135. 
Meister RT .(2010) .Crop Protection of Handbook. Wilaughby, OH.USA.

Metcalf RL (1972). Mode of action of insecticide synergist.Ann .Rev. Entomology.12:225 229.

Ozturk G, and Yildrim Z. (2013). Effect of bioactivators on the tuber yield and tuber size of potatoes. T Turkish Journal of Field Crops, 18, 82-86.

Ozturk, G, \&Yildrim Z .(2012). Field performance of in vitro sweet potato (Ipomea batatas L. [Lam]) plantlets derived fromm seedstocks. Turkish Journal of Field Crops, 17, 1-4.

Pavela R, Vrchotova N, ERA B. . (2008). Growth inhibitory effect of extracts from Reynoutria $s p$. plants against Spodoptera littoralis larvae. Agrociencia (Montecillo). 42:573-584.

Sas, S. A. S.. (2001). STAT User's Guide for Personal Computers, Release 6.12. SAS Institute Inc. Cary, NC, USA.
Scott IM, Jensen H, Scott JG, Isman MB, Arnason JT, and Philogene BJR. (2003). Botanical insecticides for controlling agricultural pests: piperamides and the Colorado potato beetle Leptinotarsa decemlineata Say (Coleoptera:Chrysomelidae). Archives of Insect Biochemistry and Physiology, 54, 212225.

Sun YP and Johnson ER . (1960). Synergistic and antagonistic actions insecticide - Synergist combinations and their mode of action. Journal of Agricultural Food Chemistry . 8(4): $261-266$.

Wilkinson CF .(1979).The use of insect sub cellular components for studying the metabolism of xenobiotics . In ( Paulson, G.D., D.S. Fear , and E.P. Marks eds )Xenobiotic metabolism in vitro method . ACS, Washington ,Pp. 249 284 
كارتيّكرنا دزوه خارنى تولفينبرايد ل سهر مندهك قر كهريّت ميّش و مورا دزى كيزّا كولورادو

(Leptinotarsa decemlineata (Say) (Coleoptera: Chrysomelidae

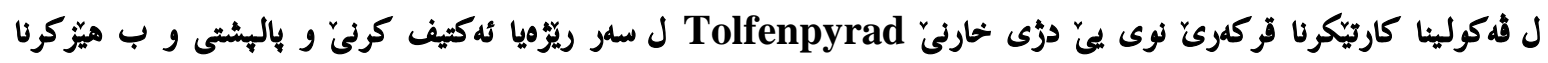

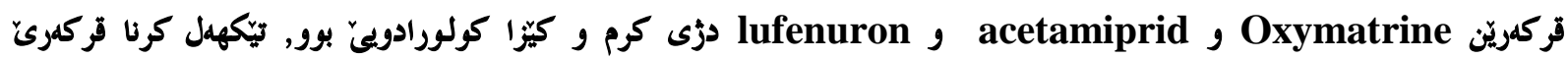

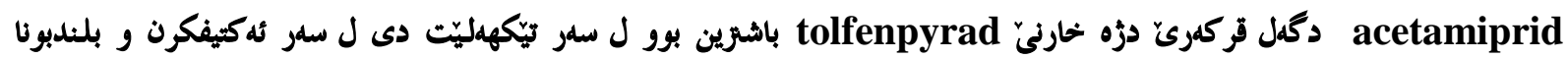

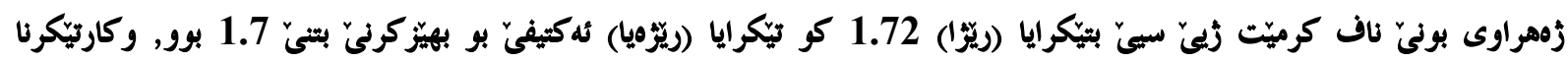

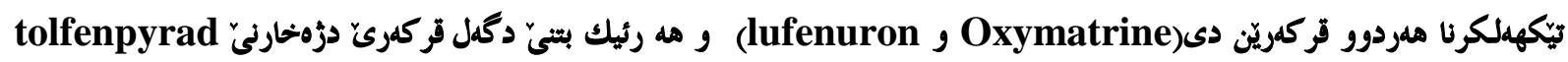

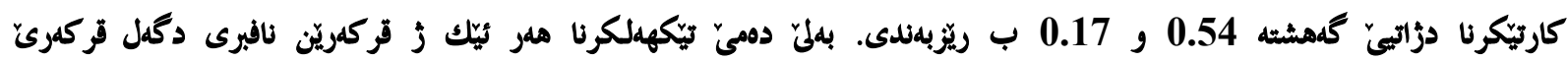
Tolfenpyrad

تأثير مانع التغذية تولفينبرايد على بعض المبيدات الحشرية ضد خنفساء كولورادو

(Leptinotarsa decemlineata[Say]) (Coleoptera: Chrysomelidae)

الخلاصة

أظهرت نتائج الدراسة تأثير مبيد جديد مانع للتغذية Hachi-Hach (Tolfenpyrad) في نسبة

التنشيط والتآزر والتقوية للمبيدات الحشرية Oxaymatherin و acetamiprid و lufenuron ضد يرقات وبالغات خنفساء كولورادو ، تفوق خليط مبيد اسيتاميبريد مع مانع التغذية tolfenopyrad في تنشيط

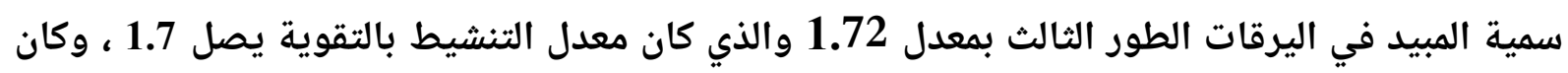
تأثير خلط مضاد التغذية التوفينوبيراد مع المبيدات الحشرية lufenuron و

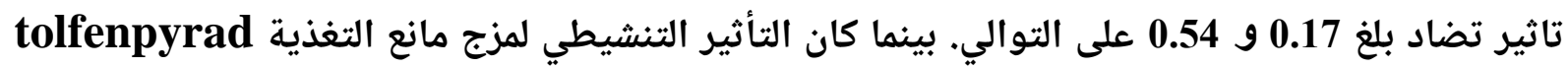
مع المبيدات المذكورة أعلاه ضد بالغات خنفساء كولورادو تأثير تضاد بلغ 0.124 و 0.524 و 0.614 على 0.54 التوالي.

الكلمات الدالة :- مانعات التغذية , تنشيط , التآزر, التقوية , خنفساء كولورادو. 